\title{
Consistency of Two Major Data Sources for Exchange Rates in the Interwar Period and Evidence on the Behaviour of Exchange Rates during Hyperinflations: The Case of Germany
}

\author{
David A. Peel and Alina M. Spiru \\ Lancaster University Management School
}

\begin{abstract}
We exploit a rather neglected source of data, The Commercial and Financial Chronicle to shed light on the behaviour of daily and weekly exchange rates throughout several interwar hyperinflation episodes, in particular the German hyperinflation. The purpose of our analysis is three-fold: firstly, we investigate the consistency of exchange rate data by comparing the rates available from this source to those provided by a widely used source, Einzig (1937). Secondly, we scrutinize the commentaries offered by The Chronicle to shed light on the impact of news on the behaviour of the US dollar/German reichsmark exchange rate over the interwar German hyperinflation, and to check whether the narrative analysis provided therein is consistent with formal econometric analyses in dating when the probability of monetary reform became significantly different from zero. Thirdly, we examine the relationship between the US dollar/German reichsmark spot rate and German wholesale prices during the high inflation period of 1923 using data at (nearly) weekly frequency. We find evidence of long- run purchasing power parity, consistent with the findings of several extant studies that employ monthly data. However, we also show that complete adjustment to purchasing power parity did not appear to occur with the nearly weekly sampled data.
\end{abstract}

\section{Introduction}

The properties of economic relationships during the German hyperinflation of the interwar period have been the focus of numerous empirical studies which employ exchange rate data. For instance, Frenkel (1977, 1979), Abel et al. (1979) and Michael et al. (1994) employed the forward premium as a determinant of inflationary expectations or currency substitution in the demand for money. Krugman (1977) and Frenkel (1980) investigated the efficiency of the forward rate as a predictor of the future spot rate. Frenkel (op. cit.), Taylor and McMahon (1988) and Michael et al. (1997), inter alia, examined the validity of purchasing power parity, whilst Webb (1986) investigated the relationship between fiscal news and inflationary expectations, employing exchange rate data in his analysis. In each of these papers, the source of German exchange rate data was the data appendix in Einzig (1937) ${ }^{1}$, which, in addition to weekly Saturday observations on the London market of the

${ }^{1}$ Einzig (1937), Appendix 1, pp. 449-481. The weekly quotations for spot and three-month forward exchange rates are for each Saturday in the interwar period and were collected from the weekly circular of the Anglo-Portuguese Colonial and Overseas Bank. 
German reichsmark's spot and forward exchange rates against the Pound sterling, also reports similar rates for other currencies ${ }^{2}$.

Whilst the quotations of the German reichsmark in the 1920s have received considerable attention due to the major hyperinflation episode witnessed by the country, the exchange rates of the other currencies reported by Einzig (op. cit.) have also been employed by many studies focusing on the interwar period (see, for example, Krugman, 1977; Frenkel, 1978; Hansen and Hodrick, 1980; Peel and Taylor, 2002 and Hsieh and Romer, 2006 ${ }^{3}$ ). In contrast to the other studies, Smith and Spencer (1991), in their analysis of the behaviour of the US dollar/Pound sterling exchange rate in the period leading up to UK's return to the Gold Standard, employed daily data from a different source, namely The Commercial and Financial Chronicle (henceforth The Chronicle).

We examined various issues of The Chronicle from the interwar period and found that in addition to the US dollar/Pound sterling spot exchange rate series used by Smith and Spencer (op.cit.), it also reports several other daily exchange rates against the US dollar. These include: the German reichsmark, the Austrian krone, the Hungarian krone and the Polish mark. Consequently, this hitherto relatively unexplored data set enables us to investigate the properties of these daily exchange rates over the interwar hyperinflation episodes of their respective countries. Furthermore, it allows us to address the important issue of whether the different data sets used in the literature provide a consistent picture of exchange rate movements during this period. ${ }^{4}$ In this study, we carry out a formal analysis of the US dollar/ German reichsmark Saturday quotations, which are available from both Einzig (1937) and The Chronicle, to determine whether they have similar statistical properties. Furthermore, we report the results of a similar exercise for the US dollar/Pound sterling exchange rate in Appendix A.

In addition to being a comprehensive source of macroeconomic and financial data, The Chronicle, which was published weekly, provides commentaries on economic, social and political developments, offering a potential rationale for market movements. These commentaries constitute a source of documentary evidence on a number of issues that are pivotal to the interpretation of the findings of empirical work covering the interwar hyperinflation period. Some of the most relevant commentaries are those on monetary reform. For instance, the precise dating of the markets' anticipation of monetary reform plays a key role in determining the appropriate date to truncate the data series in

\footnotetext{
${ }^{2}$ The Belgian franc, the French franc, the Dutch guilder, the Italian lira, the Swiss franc and the US dollar.

${ }^{3}$ Krugman (1977) investigated the validity of purchasing power parity and the efficiency of the forward exchange market for a sample of exchange rates against the US dollar. Hansen and Hodrick (1980) examined the efficiency of the foreign exchange market for the exchange rates of the French franc, US dollar and German reichsmark relative to the British pound. Frenkel (1978), Peel and Taylor (2002) and Hsieh and Romer (2006) studied covered interest arbitrage between the US and the UK.

${ }^{4}$ Bernake (2005) and Hsieh and Romer (2006) have raised this point in the context of the US dollar/Sterling pound and US dollar/ French franc exchange rate data respectively.
} 
empirical investigations of money demand or market efficiency, due to peso problems (see, e.g., Flood and Garber, 1980 and 1983; LaHaye, 1985; Casella, 1989). A second issue of interest is whether the US dollar/German reichsmark quotations during the later stages of the German hyperinflation were notional. That this could have been the case is suggested by the observation in Bresciani-Turroni (1937, pp. 126-128) that "Transactions in marks are limited to casual business or to speculation”, wrote the Frankfurter Zeitung of November $7^{\text {th }}$, 1923. [...] At New York, (according to the correspondent of the Frankfurter Zeitung), the exchange rate of the paper mark was fixed by a small group of speculators who met round a table in a café!".

Our analysis of the weekly US dollar/ German reichsmark Saturday quotations available from the two data sources suggests that they exhibit similar statistical properties and the differences, occurring mainly in the later stages of the hyperinflation, can be explained by measurement that was almost certainly at different times of the day. Given this finding, we consider in detail the properties of the daily changes in the logarithm of US dollar/German reichsmark spot rates. A brief analysis of three other exchange rates during the interwar hyperinflation periods in Austria, Hungary and Poland is carried out in Appendix B. Our analysis demonstrates that both days of dramatic depreciation and, perhaps surprisingly, appreciation, occurred during the hyperinflation period. We endeavour to relate some of these extreme movements to the narrative provided by The Chronicle.

Furthermore, our data set of daily observations, in conjunction with the weekly data on wholesale prices reported by Webb (1986) for the year 1923, allows us to analyze the behaviour of the real exchange rate in the later stages of the German hyperinflation. Previous studies addressing this topic have used monthly data, including earlier, non-hyperinflation, months ${ }^{5}$. Given our longer data series, we are able to estimate a cointegrating regression between exchange rate and wholesale prices solely for weeks in 1923. Whilst we find evidence of a long-run equilibrium purchasing power parity relationship, we also find significant short- run deviations, a result that validates the decision of Abel et al. (1979) to employ both changes in inflation and changes in spot rates in their analysis of money demand during the German hyperinflation.

We also analyze the time series properties of the daily rates of change of the US dollar/German reichsmark spot rate during the hyperinflation period 18 April 1923 to 10 August 1923, a period following the stabilization policy implemented between 21 February and 17 April 1923, and prior to

\footnotetext{
${ }^{5}$ Frenkel (1980) employed monthly data for the period February 1921 - August 1923. Taylor and McMahon (1988) used data for the period February 1921 to August 1923, and reported a long-run cointegrating relationship consistent with the purchasing power parity holding as a long-run equilibrium condition. However, Abel et al (1979, p.99), suggest, on the basis of graphical evidence on the ratio of consumer prices to the spot exchange rate that there was "considerable variation in the relative price, contrary to some tight purchasing power relationship".
} 
the date at which we identify the probability of monetary reform becoming significant. In this analysis, we find evidence of three equilibria, consistent with the model of Evans et al. (2001).

The rest of the paper is organized as follows: in Section II we examine the properties of the weekly Einzig (1937) and Chronicle quotations. In Section III, we illustrate some of the properties of the daily US dollar/ German reichsmark exchange rates. Section IV is a narrative section, which reports some commentaries retrieved from The Chronicle, in an attempt to shed light on the likelihood of monetary reform towards the later stages of the German hyperinflation and on the impact of news on the volume of trade in German marks. Section V investigates the validity of purchasing parity during the German hyperinflation episode and the time series properties of the exchange rate. Section VI offers a brief conclusion.

\section{Comparisons Between Exchange Rate Data Sets}

In order to determine whether exchange rate data from different sources exhibits similar properties we examine the weekly exchange rate returns computed as differences in the logarithm of spot rates from our two sources, Einzig (1937) and The Chronicle. Furthermore, we also examine the difference between the US dollar/ Reichsmark spot rates (in logs) available from the considered sources. For this exercise, we use Saturday quotations. Whilst The Chronicle reports the US Dollar/Reichsmark rate, the corresponding rates from Einzig (op.cit.) are inferred as cross rates, using the US dollar/Pound and the Reichsmark/Pound spot rates available from this source.

Table 1 below reports descriptive statistics for these series over the period 28 May - 24 November 1923, suggesting that the weekly returns based on the two data sources exhibit very similar sample characteristics. We also plot the difference between the logarithms of the exchange rates from the two sources in Figure 1. Whilst the maximum and minimum differences are comparatively large, the mean of the differences over the sample period is comparatively small at $1.39 \%$. Figure 1 reveals that the difference in quotations attained higher values towards the end of the sample, which reflects the different timing of quotations during the day in the later stages of the German hyperinflation. To give a few examples, some substantive discrepancies have been recorded on 16 January 1923 (-0.139), 6 October 1923 (0.5449), 24 November 1923 (-0.351). 
TABLE 1

DESCRIPTIVE STATISTICS FOR DOLLAR/REICHSMARK SATURDAY QUOTATIONS

\begin{tabular}{|c|c|c|c|}
\hline Descriptive Statistics & $\begin{array}{l}\text { Weekly returns based } \\
\text { on Einzig (1937) }\end{array}$ & $\begin{array}{l}\text { Weekly returns based } \\
\text { on The Chronicle }\end{array}$ & $\begin{array}{l}\text { The difference in } \\
\text { weekly (Saturday) } \\
\text { quotations between } \\
\text { Einzig and The } \\
\text { Chronicle }\end{array}$ \\
\hline Median & -0.0742 & -0.0860 & 0.0115 \\
\hline Maximum & 0.5754 & 0.4383 & 0.5449 \\
\hline Minimum & -3.3159 & -3.2342 & -0.3509 \\
\hline Std Deviation & 0.4539 & 0.4415 & 0.0735 \\
\hline Skewness & -3.8014 & -3.5491 & 1.9447 \\
\hline Kurtosis & 22.5873 & 20.8965 & 27.1722 \\
\hline
\end{tabular}

FIGURE 1

THE DIFFERENCE IN LOG (SATURDAY) QUOTATIONS BETWEEN EINZIG (1937) AND THE

CHRONICLE

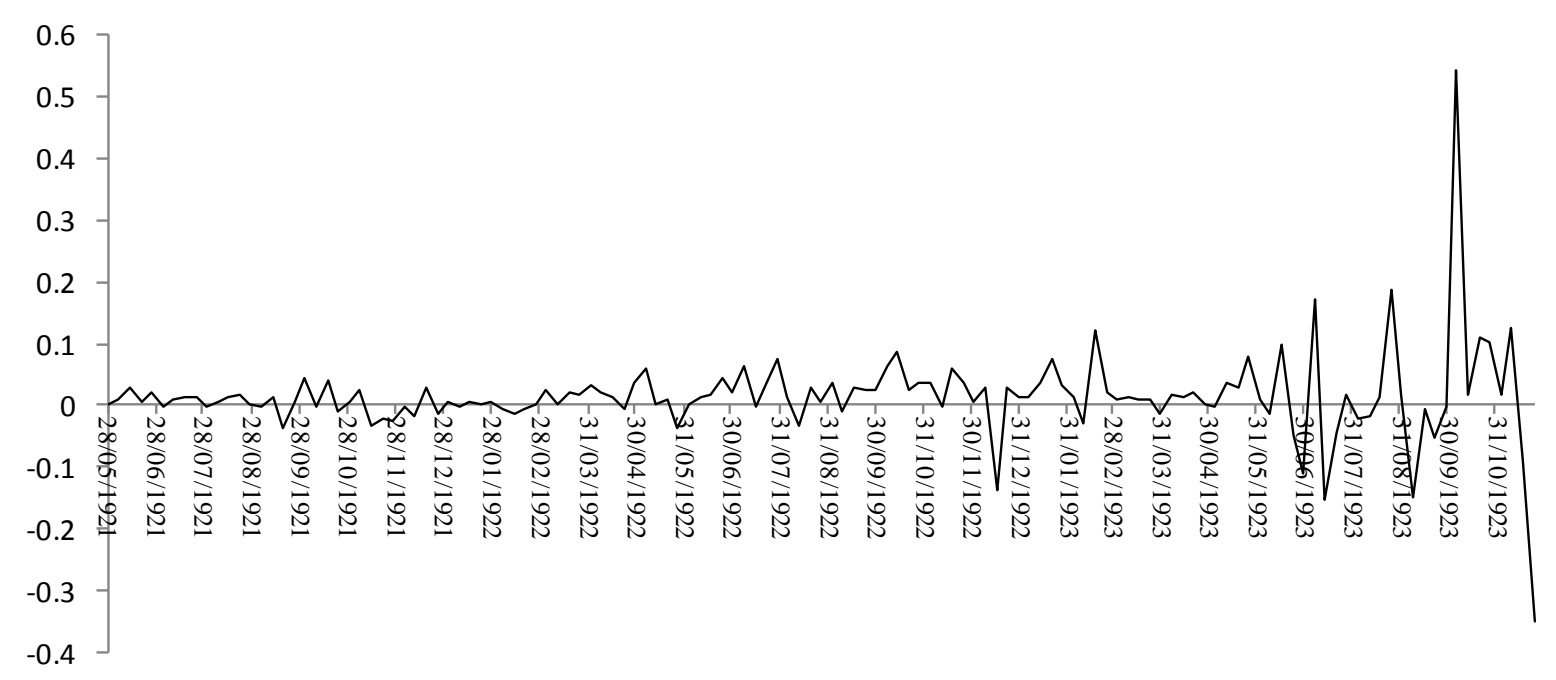


To further illustrate the similar properties of the data, we estimated a simple regression between the weekly returns computed using the two data sets. The results suggested that the relationship in the rates of change of Saturday quotations is a strong one. For example, for the hyperinflation period 7 July $1922-24$ November 1923, we obtained:

$$
\begin{aligned}
\text { DLNEIN }=- & -0.0042+1.0036 \text { DLNCH } \\
& (0.0175) \quad(0.0277) \\
& \bar{R}^{2}=0.9474
\end{aligned}
$$

where DLNEIN denotes the weekly exchange rate returns calculated using Saturday quotations from Einzig (1937) and DLNCH represents weekly returns based on Saturday quotations from The Chronicle. Standard errors are in ( ).

We observe that the estimate of the constant is near zero and the slope coefficient is insignificantly different from unity. The high correlation between the two exchange rate series is clear from observation of Figure 2, which illustrates the weekly returns computed using the two data sources. 


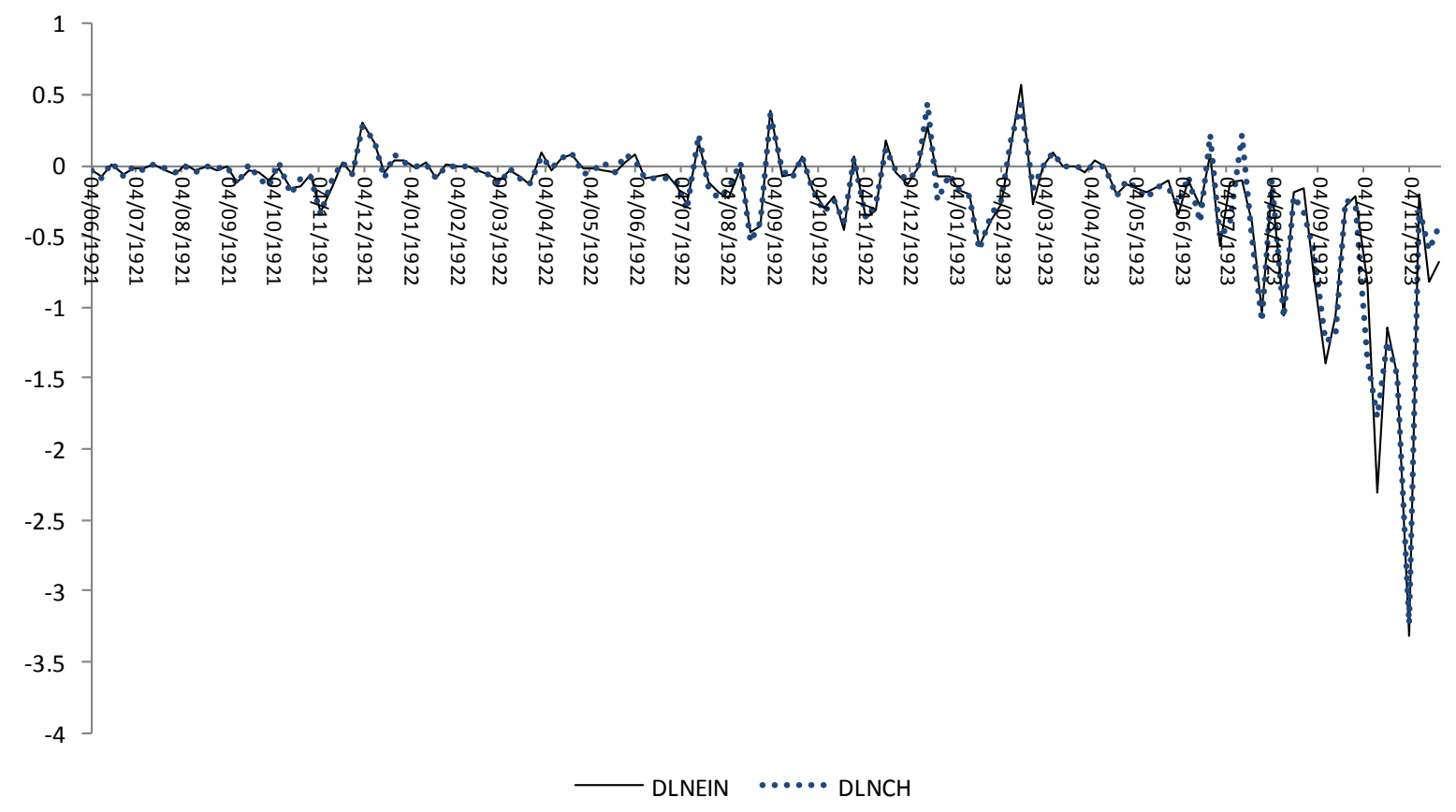

Notes:

DLNEIN = weekly returns (differences in logarithms) based on US Dollar/Reichsmark Saturday quotations from Einzig (1937)

DLNCH = weekly returns (differences in logarithms) based on US Dollars/Reichsmark Saturday quotations from The Chronicle

As a further check on the data sources, we carried out the same exercise for the US dollar/British pound exchange rate. The results, which are reported in Appendix A, also show that the two data sources are exhibiting very similar properties.

Given the similar properties of the Saturday US Dollar/Reichsmark quotations, in the next section we consider in more detail the properties of the daily exchange rate data.

\section{The Properties of the Daily German Spot Exchange Rates}

The sample properties of the daily data are reported in Table 2. This table, together with Figure 3, reveals the great volatility exhibited by the daily changes in the spot exchange rate. This feature of the data was commented on by Bresciani-Turroni (1937, pp 126-128) quoted in the introductory section of this paper. 
TABLE 2

DESCRIPTIVE STATISTICS FOR THE DAILY CHANGE IN (LOG) US DOLLAR/REICHSMARK QUOTATIONS

\begin{tabular}{lcc}
\hline Statistics/ Sample & 28 May 1921-24 November 1923 & 1 May 1923 - 24 November 1923 \\
\hline Mean & -0.0336 & -0.1105 \\
Median & -0.0067 & -0.0714 \\
Maximum & 1.6414 & 1.6414 \\
Minimum & -2.3026 & -2.3026 \\
Std Deviation & 0.1705 & 0.3244 \\
Skewness & -2.8563 & -1.1141 \\
Kurtosis & 61.2697 & 19.1100 \\
\hline
\end{tabular}

Notes: Data source: The Chronicle

FIGURE 3

DAILY RATES OF CHANGE OF US DOLLAR/ REICHSMARK QUOTATIONS

(A) Sample 28 May 1921 - 24 November 1923

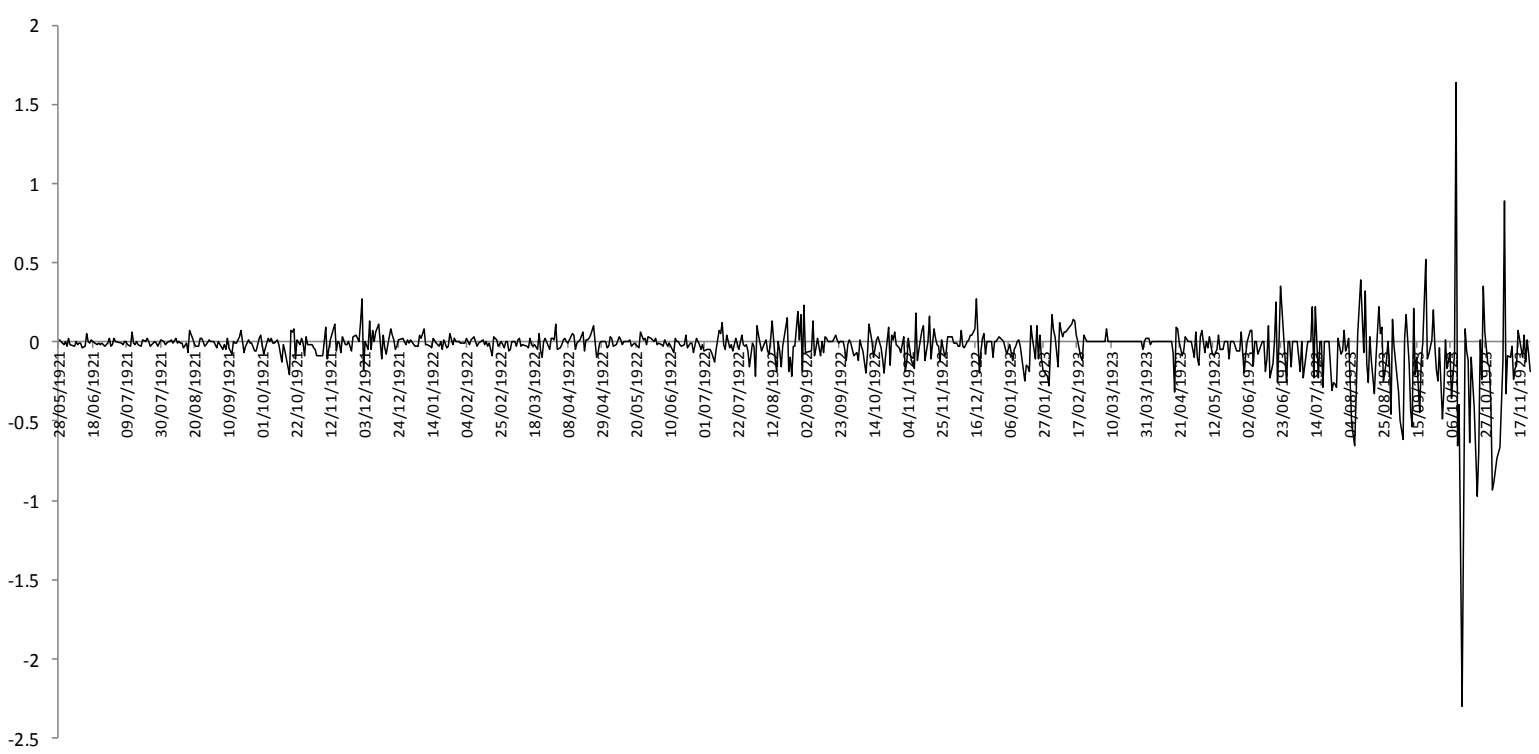




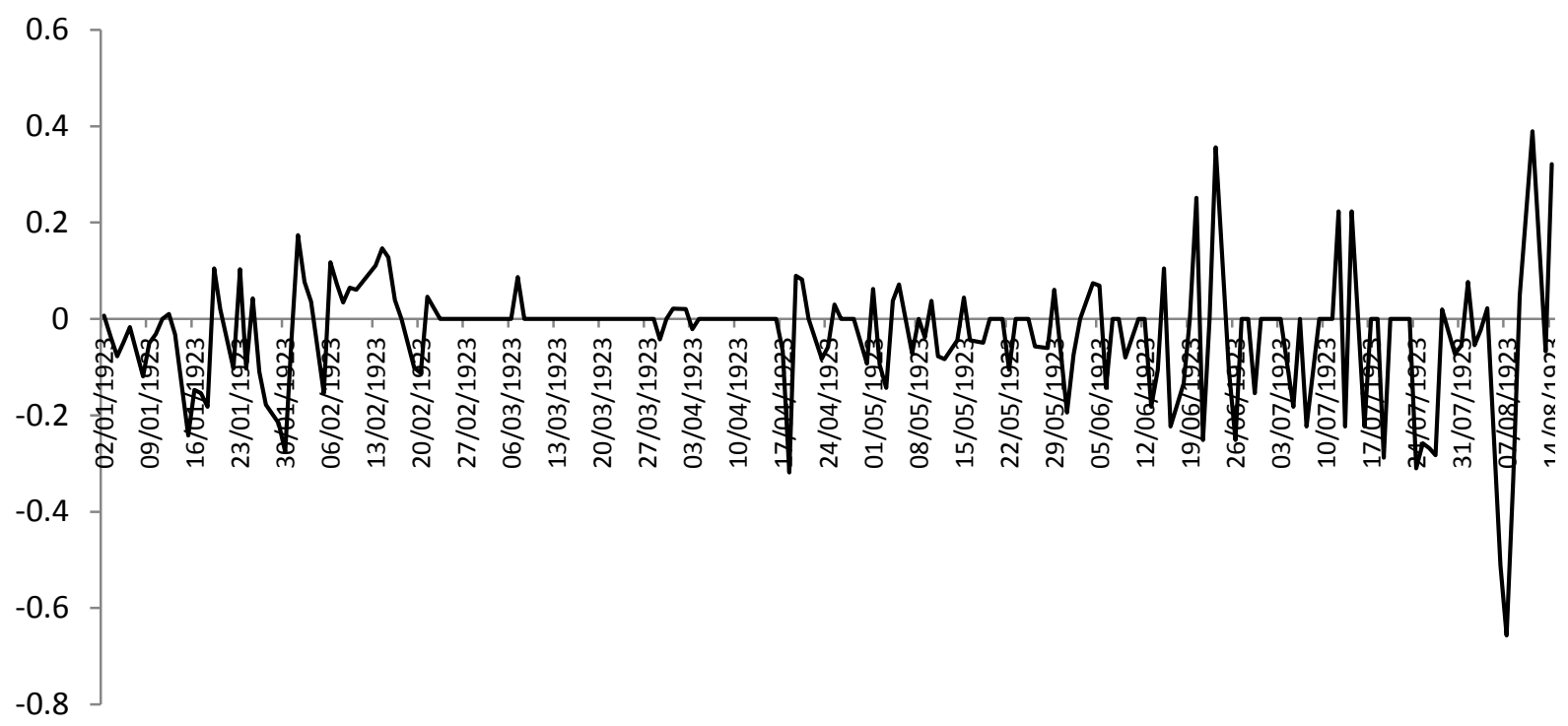

The Chronicle data does in fact display a pattern which essentially accords with the observations of Breciani-Turroni (1937). On April $6^{\text {th }}$, April $8^{\text {th }}$, April $11^{\text {th }}$ and April $14^{\text {th }} 1923$, the quotations in Marks per Dollar were 1.8, 5, 3.2 and 2.5 million Reichsmarks per Dollar. As a further indication of the volatility, between 16 April and 1 September 1923 there were twenty seven days on which the spot rate appreciated with an average of $11.99 \%$. Also, in the period 1 September to 24 November 1923 there were sixteen days on which the spot rate appreciated with an average of $26.76 \%$ and with a maximum of $164 \%$ and a median of $6.64 \%$. Of course, these dramatic appreciations could simply reflect good news. As stressed by Webb (1986, pp. 769 - 770), "Important fiscal news included not only matters narrowly related to the budget, like tax reforms and Allied reparations demands, but also challenges to the government's authority-armed uprisings and foreign invasions". However, despite allowing for a larger connotation for the concept of 'news', a la Webb (op. cit.), and its impact on exchange rates, the magnitude of the appreciations we detect in the data is still somewhat surprising given the dramatic depreciations taking place over the same period ${ }^{6}$.

Figure 3 (B) shows the impact of the stabilization policy enacted between 21 February and 16 April 1923, when the Reichsbank intervened in the foreign exchange market in support of the Reichsmark exchange rate ${ }^{7}$.This policy resulted in near constancy of the exchange rate over this period.

\footnotetext{
${ }^{6}$ We would note in this context that Hansen and Hodrick (1980) report evidence on the determinants of excessive returns to currency holdings that are consistent with inefficiency in the foreign exchange markets in this period.

${ }^{7}$ Table 3 in Webb (1986, p.788) and the commentary in Bresciani-Turroni (1937) illustrate the same features.
} 


\section{The Prospects of Monetary Reform and the Trading in Marks Towards the Final Stages of the German Hyperinflation: A Narrative Analysis}

Precise dating of when economic agents' probability of monetary reform ceases to be negligible is critical in formal econometric analysis of speculative bubbles or appropriate dating of samples to avoid peso problems. Consequently, it is of interest to determine if The Chronicle commentary might provide some narrative evidence in support of the formal analysis conducted by Flood and Garber (1983) and LaHaye (1985), who investigated econometrically the likelihood of a monetary reform. These authors assumed rational expectations and based their estimates of the date of monetary reform on estimates of the money supply process. Their analyses suggest that agents had a negligible probability of monetary reform having occurred or not expecting it to occur until after mid August 1923 and varied considerably over the next ten weeks.

By scrutinising the weekly commentaries provided in various issues of The Chronicle (a selection of which is included in Box 1 below), we found several salient mentions of monetary reform ${ }^{8}$. It is important to note that the first mention of monetary reform in the Chronicle occurs on 11 August 1923, which accords with the formal analyses carried out by Flood and Garber (op. cit.) and LaHaye (op.cit.).

\footnotetext{
${ }^{8}$ The Chronicle also mentions monetary reform as a possibility on 10 October 1923 for the other countries witnessing hyperinflation: "Recent advices from Central Europe are to the effect that a number of the European nations are considering the advisability of instituting new currency systems". Among those mentioned are Austria, Hungary and Poland, each of which is said to be planning to establish stable units of currency.
} 
BOX 1

COMMENTARIES ON THE LIKELIHOOD OF A MONETARY REFORM

Date

Week ending

11 August 1923

\section{Commentary}

“Absolute withdrawal of Reichsbank's regulations in the matter of dealings in mark exchange and rumours that Germany was planning to repudiate the mark and restore the Gold currency added to the general confusion and served to still further complicate matters, the result being a series of amazing declines in the value of Reichsmark, already close to nil, bringing quotations down to almost infinitesimally low figures"

Week ending 25 August 1923

"On August $17^{\text {th }}$ the representative in the German capital of the New York Herald said that 'the Government's efforts to put German finances upon a gold basis have met with a sharp setback'. The New York Tribune correspondent asserted that 'the Reichsbank still continues to refuse to cooperate with the Government in its plan to stabilize the currency"

Week ending

15 September 1923 "Renewed rumours that the German government is planning to form a new bank of issue which will circulate currency based on gold reserves, and
probably utterly repudiate the present mark, had a disastrous effect on values and brought about a sharp slump in mark values to a microscopic $0.00000075(88,000,000$ mark to an US\$)"

Week ending

“German marks were chiefly influenced by political uncertainties, publication of further details of Chancellor Stresemann's plan for establishment of a

22 September 1923 gold currency to supersede marks and further colossal additions to the Reichsbank's note issue"

Week ending 20 October 1923

“Notwithstanding announcement that the Stresemann government had decided to stop the printing of marks at an early date, last week's German Bank statement recorded a colossal increase in note circulation, nearly quadrupling the total amount outstanding. The next statement is looked forward to with considerable interest"

Week ending

27 October 1923

"It was reported towards the end of the week that the printing of the new gold currency had commenced. RM sank to still lower depths and the quotation (nominal so far as this market is concerned) was reduced to the incredible minute figure of 0.0000000010 , the equivalent of $100,000,000,000$ marks for $\$ 1 "$

Week ending

10 November 1923

"No real improvement is looked for, however, while the Reichsbank's issue of note circulation continues at its present unparalleled rate. Although at the close there was a rally to 0.000000000045 . The new Gold-backed German currency is now available, but thus far dealers are displaying caution in their handling of rentenmarks"

Week ending

"Talk of the formation of a group of leading American banks for the purpose of negotiating a large German loan aroused some attention, but very little

17 November 192315 and that after that date it would no longer be necessary to meet the needs of the Reichsbank by the printing of paper marks. Bankers here take the view that the all important point just at present is adjustment of reparations problems"

Week ending

24 November 1923

"Very little hope is entertained of bringing about any improvement in German exchange conditions, in the absence of genuine monetary reform. Issuance of paper marks on a colossal scale had an unfavourable effect. It is considered impossible for the Government to balance its budget under the present abnormal situation. Intimations that the use of the new rentenmark is increasing rapidly had little effect on sentiment" 
In addition to comments on economic, social and political events, The Chronicle offers a number of comments concerning the volume of trade in Reichsmarks. It would appear from these that trade continued in foreign centres (that is outside Germany) after 18 August 1923, but became negligible after 8 October 1923, in foreign centres though still continuing; for instance, see in particular the comments of August $18^{\text {th }}$, October $6^{\text {th }}$ and November $10^{\text {th }} 1923$. The commentary in The Chronicle also highlights newsworthy events which are assumed to impact on the exchange rate. Some examples, relevant to both issues, are set out below?

${ }^{9}$ Additional comments, not reported here, are available from the authors upon request. 
Week ending

"Marks rates were forced down to a new low record, namely $0.0003 \frac{11}{4}$. Subsequently, there was a partial rally and the quotation moved up to $0.00051 / 4 \mathrm{c}$., on hopes of some

Week ending new movement to the end of the Ruhr occupation, but before the close of the week fresh weakness set in"

Week ending

"Locally, dealers are exhibiting marked caution in taking on commitments in these exchanges, though some speculative transactions for moderate amounts were recorded.

21 July 1923 Attempts to sell on the part of foreign holders, however, are still in evidence and were responsible for the
reparations issue and here also dealers are anxiously awaiting a decision on this momentous question"

Week ending

"The feature of the week, however, was the further decline in the value of the Rei

28 July 1923 on market sentiment of another phenomenal expansion in note circulation..."

Week ending

4 August 1923

“Trade was erratic and the undertone nervous and confused. In a word, the market was unusually susceptible to 'bad' news and responded to the many unfavourable rumors circulating in the financial district by sharp loses in values. This is especially true of Marks, which, as a result of disappointing reparations news, intimations of internal political upheaval and a further spectacular expansion in Reichsbank's note circulation, were forced down to 0.000083. Drastic action of Imperial Bank of Germany in raising discount rate to $30 \%$ failed to exert any appreciable influence upon mark quotations"

"The early weakness of course, reflected re collapse of the Cuno government and the coincident internal political disorders. Subsequently with the suppression of rioting and "The early weakness of course, reflected re collapse of the Cuno government and the coincident internal political disorders. Subsequently with the suppression of rioting and
resumption of order, coupled with adoption of a more conciliatory attitude by Chancellor Stresemann, the quotations steadied, and it was claimed that supporting orders were

Week ending put forth for substantial amounts. Bankers and traders alike take an optimistic view of the change in the German cabinet, but are extremely wary in the matter of actual dealings. A majority of the banks are said to have ceased trading in German exchange; others deal on customers' orders only."

18 August 1923

"With receipt of the news of yesterday's quotation of the mark in New York, showing a decline of $100 \%$ in 24 hours, registering a low record, the feeling quickly developed

Week ending into a widespread insistence that the country is again on the brink of another political and social paroxysm"

25 August 1923

"German marks were heavy practically throughout and not only did not respond favourably to rumours of the possibility that France and Germany might open negotiations looking to an agreement in the reparations dispute, but were actually forced down an additional 0.000003 points, to the infinitesimal figure of 0.000010 . At this price, a dollar would purchase 10,000,000 marks. The decline was attributed mainly to the demoralized financial conditions in Germany, and followed publication of an amazing bank statement which showed the largest expansion of note circulation: well over 54 trillion marks. Recent dispatches outlining new measures to protect exchange exercised little or no influence. Bankers here predict that the latest effort to levy a forced gold loan will fail as all such attempts in the past have failed"

Week ending

1September 1923

\begin{tabular}{ll}
$\begin{array}{l}\text { Week ending } \\
\text { 8September 1923 }\end{array}$ & $\begin{array}{l}\text { "As to marks, unabated Reichsbank note expansion coupled with ever-increasing efforts to dispose of the mark holdings completely offset the betterment in the outlook for } \\
\text { settlement of Germany's reparation difficulties and German exchange values plunged further downwards" }\end{array}$ \\
\hline
\end{tabular}


Week ending

15 September 1923

"Following recovery at the end of last week at 0.000003 , renewed rumours that the German government is planning to form a new bank of issue which will circulate currency based on gold reserves, and probably utterly repudiate the present mark, had a disastrous effect on values and brought about a sharp slump in mark values to a microscopic $0.00000075(88,000,000$ mark to an US $\$)$. The mark closed at 0.00000090 after a small recovery. Continued unloading of marks by German interests and still another huge expansion in the output of note circulation all combined to force down prices"

"German marks were chiefly influenced by political uncertainties, publication of further details of Chancellor Stresemann's plan for establishment of a gold currency to

Week ending

22 September 1923

supersede supersede marks and further colossal additions to the Reichsbank's note issue. Advance in German bank rate to $90 \%$ manifestly could not serve to arrest the decline in m
quotations, which were forced down to the infinitesimal figure of 0.00000035 , another new low record, and approximately $285,712,000$ marks to the dollar. (as mark remained weak at 0.00000035 , equivalent to $285,712,000$ marks to 1 US\$) Subsequently Mark rallied back to 0.00000100 wholly on the speculative buying by German interests hopeful of a speedy agreement with France" "RMs did not respond as readily to improved prospects of settlement of Germany's reparation difficulties and after weakness in the early dealings, the grotesquely low
quotation recovered 0.00000042 points to 0.00000100 . Later the quotation sagged off again to 0.00000049 , but it subsequently seemed as if the German government had quotation recovered 0.00000042 points to 0.00000100 . Later the quotation sagged off again to 0.00000049 , but it subsequently seemed as if the German government had
resumed support of the mark to relieve the growing tension in Germany over the complete collapse of mark values, which it was feared might lead to overthrow of the Stresemann regime."

Week ending

29 September 1923

Week ending

6 October 1923

"Indications of another political upheaval in Berlin for a while aroused widespread alarms and the mark values were again attacked, further progress being made in the process of complete devaluation. The quotation at one time was down to the infinitesimal figure of 0.00000018 , a loss of 0.00000042 points. At this level, over 400 , 000,000 marks could have been purchased for a dollar, though so far as the local market is concerned, the quotation carried no meaning whatsoever, since the German exchange is not being dealt in. At London and other financial centres in Europe distress offerings of marks continue to be made with very few takers even at the most extreme concessions".

"Developments regarding the reparations tangle and Chancellor Streseman's efforts to restore some semblance of political order in Germany were factors of considerable importance, but probably the most potent influence in deciding actual values was the volume of commercial bills offering. RMs failed to reflect the more hopeful utterances from Berlin earlier in the week, and after a while broke severely on what appeared to be another serious political upheaval in Germany. In the late dealings the whole foreign exchange market firmed up on more cheerful reports from abroad, which included the French, British and Italian agreement to use Belgium's reparation plan as propounded in June for the basis of a new plan of settlement with Germany, resumption of work in many parts of the Ruhr and indications of subsistence of rioting in Berlin and other important German centres. Notwithstanding announcement that the Stresemann government had decided to stop the printing of marks at an early date, last week's German Bank statement recorded a colossal increase in note circulation, nearly quadrupling the total amount outstanding. The next statement is looked forward to with considerable interest.. RMs finished at 0.000000085 for both checks and cable transfers, against 0.00000002 the previous week."

Week ending

20 October 1923

"While very little business in marks is being done locally, it is understood that in London and the continent there is still a demand for marks, largely from speculative

Week ending

10 November 1923 interests who believe that pre-war currency will be recognized in the final readjustment of currency. No real improvement is looked for, however, while the Reichsbank's issue of note circulation continues at its present unparalleled rate. Although at the close there was a rally to 0.000000000045 "

"RMs were adversely affected not only by the hitch in the reparations program, but by the reports that the German government was about to repudiate the Versailles Treaty and also to declare an autonomous Rhineland state. Various conflicting reports as to the progress of events caused considerable backing and filling and prices fluctuated erratically, with the extremes 0.000000000044 and 0.000000000015 , figures that are virtually worthless so far as actual transactions in this market are concerned. Talk of the formation of a group of leading American banks for the purpose of negotiating a large German loan aroused some attention, but very little notice was taken of the

Week ending

17 November 1923 announcement that the German authorities had made arrangements to begin the issuance of the new rentenmark on Nov 15 and that after that date it would no longer be necessary to meet the needs of the Reichsbank by the printing of paper marks. Bankers here take the view that the all important point just at present is adjustment of reparations problems"

"RMs shared in the general weakness, but changes in the nominal and meaningless quotations were comparatively small, and the range for the week was 0.00000000015 to 0.000000000020 . No dealings in this class of currency were reported locally, but it is claimed that selling is still attempted abroad. Very little hope is entertained of bringing about any improvement in German exchange conditions, in the absence of genuine monetary reform. Issuance of paper marks on a colossal scale had an unfavourable effect. It is considered impossible for the Government to balance its budget under the present abnormal situation. Intimations that the use of the new rentenmark is increasing rapidly had little effect on sentiment..RMs finished at 0.000000000015 for both checks and cable transfers, the same as last week" 


\section{Purchasing Power Parity in 1923 Employing Near- weekly Sampled Data and the Time Series Properties of the Spot Exchange Rate}

We employ the natural logarithm of the wholesale price index retrieved from the percentage changes in this index reported in Webb (1986, Table 3 for four dates of each month) and the natural logarithm of the US dollar/German reichsmark spot exchange rates (from The Chronicle) corresponding to the dating of the wholesale price data ${ }^{10}$ over the period 30 December 1922 - 7 August 1923, terminating the period prior to agents' probability of monetary reform becoming significant. The values of the proxy for the real exchange rate values are then calculated as the difference in these two variables; given that the monthly US wholesale price index did not exhibit much variation and was stationary, its omission from the relationship is only of qualitative significance.

We normalize our proxy for the logarithm of the real exchange rate at the end of December 1922. Figure 4 below is a plot of the normalized rate. We observe that this measure of the real rate exhibits considerable volatility.

\section{FIGURE 4}

\section{THE LOGARITHMIC REAL EXCHANGE RATE NORMALIZED AT 30 DECEMBER 1922}

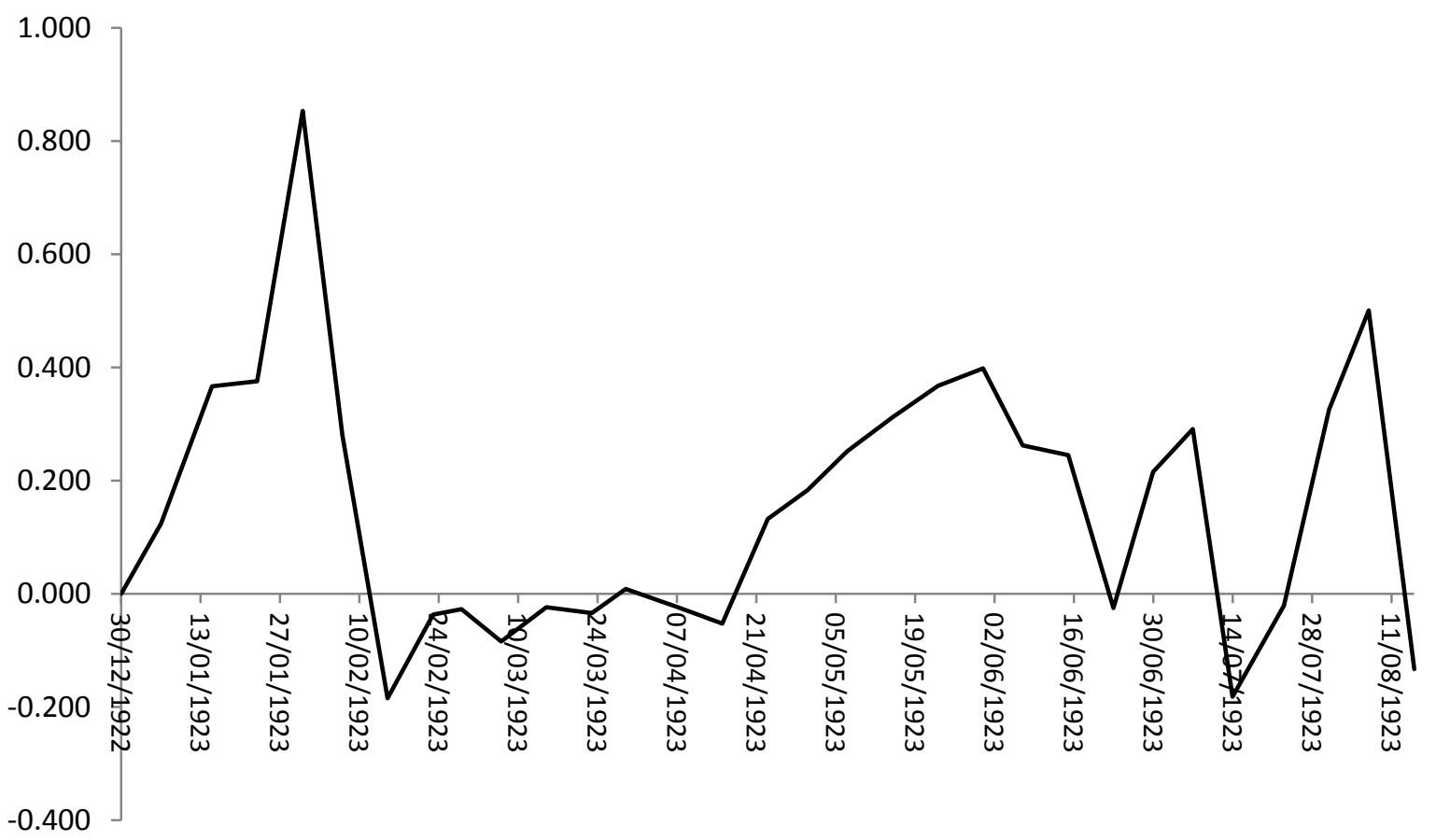

${ }^{10}$ The changes in the wholesale price index employed here are calculated as chain values, with reference to the previous date when exchange and price level data were sampled. Sampling of the dates is irregular, at intervals usually of 8-9 days rather than weekly. 
In Model 1 below we report the regression between the logarithm of the spot exchange rate and the logarithm of wholesale prices. This can be interpreted as a cointegrating regression since both series are non-stationary. The slope coefficient is estimated as near unity. The residuals from the regression pass diagnostic tests for stationarity. When we impose a unit coefficient, we also can reject nonstationarity. Consequently, given the obvious caveats regarding the relatively short data span, purchasing power parity appears to hold as a long-run condition of this high inflation period as well as the longer period analysed by Taylor and McMahon (1988) using monthly data. In Model 2 we report a significant first- order autoregressive structure in the real exchange rate, which illustrates a rather incomplete adjustment of the spot rate to the wholesale price level. However, the autoregressive coefficient raised to the power four suggests near complete adjustment within one month albeit with a large stochastic noise. These results offer support to the analysis of Abel et al (1979, p99) in employing both inflation and changes in spot rates as determinants of the opportunity cost of holding money.

Over the period 18 April to 9 August 1923, following the stabilization policy enacted in Germany between 21 February and 17 April 1923, and prior to the date at which we identify the probability of no monetary reform becoming significantly different from unity ${ }^{11}$ there are 97 daily observations of the spot exchange rate. Whilst this is a relatively short sample, analysis of the time series properties of the spot rate during this hyperinflation period appears of interest. Daily percentage rates of change over this period appear stationary ${ }^{12}$ and a random linear process in mean can be detected though exhibiting significant ARCH effects ${ }^{13}$. The analysis of hyperinflation episodes conducted by Sargent and Wallace (1973) revealed that the assumption that the authorities finance a given real budget deficit by printing money implies that inflation will follow a non-linear process which can exhibit two equilibria, the stabilities of which depend upon the process determining expectations. Evans et al. (2001) extend the analysis to a model embodying heterogeneous expectations of inflation. They demonstrate that with adaptive learning and for a wide range of parameter values, there can exist three equilibria, of which two can be stable including the high inflation equilibria. The ESTAR non-linear model can exhibit up to three equilibria and consequently is a prime candidate for analyzing the daily rates of change of the spot rate. In model 3 below we report the estimates of an ESTAR model. The most parsimonious model of the conditional mean is estimated jointly with a component ARCH $(1,1)$ model assuming a generalized error distribution. The residuals or standardized residuals from the estimated model are free from significant serial correlation or ARCH effects on the basis of LM tests of any relevant order.

\footnotetext{
${ }^{11}$ In line with the conclusion that "the probability of no reform is essentially unity prior to mid-August 1923" (LaHaye, 1985, footnote 18).

${ }^{12}$ As illustrated by a Dickey-Fuller test statistic of -8.92 .

${ }^{13}$ As illustrated by a p-value for the LM-ARCH test of order 4 of 0.001 .
} 
The estimated ESTAR model in this hyper inflation period exhibits three equilibria, with the point estimates of the parameter values giving estimates of the steady state rates of depreciation as $-78.5 \%$. -84.18 and $-89.5 \%$ per day. Stability analysis reveals that the lower and higher equilibria are stable with the middle one being unstable. Whilst the analysis is based on relatively few observations, with all the usual caveats, given that the equilibria are close together, this analysis is suggestive that the spot rate over this period would ultimately depreciate by around seventy eight to eighty nine percent in the absence of shocks.

Model 1: The regression of the log of the nominal US dollar/Reichsmark exchange rate (LGEEX) on the log of the German wholesale price index, LGEWPI, over the period 30 December $1922-7$ August 1923

$L G E E X=0.11+1.027 L G E W P I$

$$
\text { (0.07) (0.032) }
$$

$\overline{\mathrm{R}}^{2}=0.977$

$\mathrm{DW}=0.89$

Model 2: The regression of the log of the real US dollar/Reichsmark exchange rate (LGEREX) on its first lag $(\operatorname{LGEREX}(-1))$ over the period 30 December $1922-7$ August 1923

LGEREX $=0.09+0.51 \operatorname{LGEREX}(-1)$

$\bar{R}^{2}=0.25$

$\mathrm{DW}=1.68$

$\operatorname{ARCH}(1)$ LM test $p$-value $=0.94$

Model 3: ESTAR model of conditional mean for daily percentage changes in the logarithm of the nominal exchange rate (DLGEEX) over the period 18 April 1923 to 9 August 1923

$D L G E E X=-84.17+2.01[\operatorname{DLGEEX}(-1)+84.17] \cdot e^{-0.0001 \cdot(14.48)^{2} \cdot(\operatorname{DLGEEX}(-1)+84.18)^{2}}$

$\bar{R}^{2}=0.15$

$\mathrm{DW}=1.62^{14}$

\footnotetext{
${ }^{14} \mathrm{ARCH}$ and serial correlation LM tests for the residuals for the jointly estimated component $\mathrm{ARCH}(1,1)$ model reject the hypothesis of significant $\mathrm{t}$ serial correlation or ARCH at all normal significance levels. 14.48 is the standard deviation of daily percentage changes in the spot rate.
} 


\section{Concluding Remarks}

The Chronicle provides a neglected source of data on the behaviour of daily exchange rates throughout several interwar hyperinflation episodes ${ }^{15}$. This is complemented by extensive weekly market commentaries. Building on these considerations, in this paper we first examined whether The Chronicle quotations exhibited similar statistical properties to those of the weekly data from Einzig (1937). Our statistical analysis for both the US dollar/Reichsmark and the US dollar/British pound ${ }^{16}$ exchange rates showed that this was the case. We then investigated further the statistical properties of the daily exchange rate series. We observed that the German currency exhibited numerous days of large appreciations in the midst of dramatic depreciations; this feature is not apparent in the weekly Einzig data. Similar properties, albeit in the presence of much lower volatility, are observed during the Austrian, Hungarian and Polish hyperinflations, analysed in Appendix B of this paper.

To shed light on the impact of economic and social events and news on the behaviour of the US dollar/German reichsmark exchange rate over the interwar German hyperinflation, we examined the comprehensive commentary provided by The Chronicle. This commentary offers documentary evidence of two important issues. First, the commentary is consistent with the formal econometric analysis of Flood and Garber $(1980,1983)$ and LaHaye (1985) in dating when the probability of monetary reform became significant, namely mid-August 1923 . Second, the commentary suggests that there was a sufficient volume of trade in German currency, certainly in non-German centres to regard the quotes in Einzig (1937) or The Chronicle as more than simply notional until late November 1923.

Using the daily quotes from The Chronicle and the four- time monthly sampled wholesale price data from Webb (1986) we examined the relationship between the US dollar/German reichsmark spot rate and German wholesale prices during the high inflation period of 1923. We found evidence of longrun purchasing power parity, consistent with the findings of several extant studies employing monthly data for the period 1922-1923. However, we also showed that complete adjustment to purchasing power parity did not appear to occur with the nearly-weekly sampled data.

An analysis of daily percentage changes in the spot rate over the later stages of the German hyperinflation suggested this series followed a nonlinear process that was consistent and which exhibited stable long-run steady state depreciation rates of between seventy eight and eighty nine percent.

\footnotetext{
15 The data set employed in this paper is available from the authors upon request.

${ }^{16}$ Reported in Appendix A.
} 


\section{Appendix A}

We complement the analysis carried out in Section II of the paper with a similar exercise. W examine weekly logarithmic changes and the difference in weekly quotations (computed as differences in the natural logarithms of the spot rates) of another exchange rate extensively used in empirical studies that focused on the 1920s, the US dollar/British pound rate. We compare the Saturday quotations for this exchange rate available from two sources: Einzig (1937) and The Chronicle, as compiled by Smith and Spencer (1991).

Table A1 below reports several descriptive statistics for these series, suggesting that the weekly returns based on the two data sources exhibit very similar sample characteristics.

TABLE A1

DESCRIPTIVE STATISTICS FOR US DOLLAR/ BRITISH POUND QUOTATIONS

Sample: 6 May 1922 - 29 December 1923

\begin{tabular}{lccc}
\hline \hline Descriptive Statistics & $\begin{array}{l}\text { Weekly returns based } \\
\text { on Einzig (1937) }\end{array}$ & $\begin{array}{l}\text { Weekly returns based } \\
\text { on The Chronicle }\end{array}$ & $\begin{array}{l}\text { The difference in } \\
\text { weekly (Saturday) } \\
\text { quotations between } \\
\text { Einzig and The } \\
\text { Chronicle }\end{array}$ \\
\hline Mean & & & -0.0001 \\
Median & -0.0003 & -0.0003 & -0.0001 \\
Maximum & -0.0005 & -0.0001 & 0.0043 \\
Minimum & 0.0168 & 0.0194 & -0.0078 \\
Std Deviation & -0.0207 & -0.0234 & 0.0013 \\
Skewness & 0.0057 & 0.0061 & -1.5776 \\
Kurtosis & -0.1857 & -0.2431 & 16.77769 \\
\hline
\end{tabular}

The figures for the maximum and minimum differences and the mean of the difference over the sample period, which is very small, provide evidence in support of consistency of the data from the two sources we analyse. 
We also plot the difference in the logarithms of the exchange rates from the two sources in Figure A1.

FIGURE A1

COMPARISON OF THE DIFFERENCE OF WEEKLY (SATURDAY) LOGARITHMIC

QUOTATIONS FOR THE US DOLLAR/ BRITISH POUND RATE

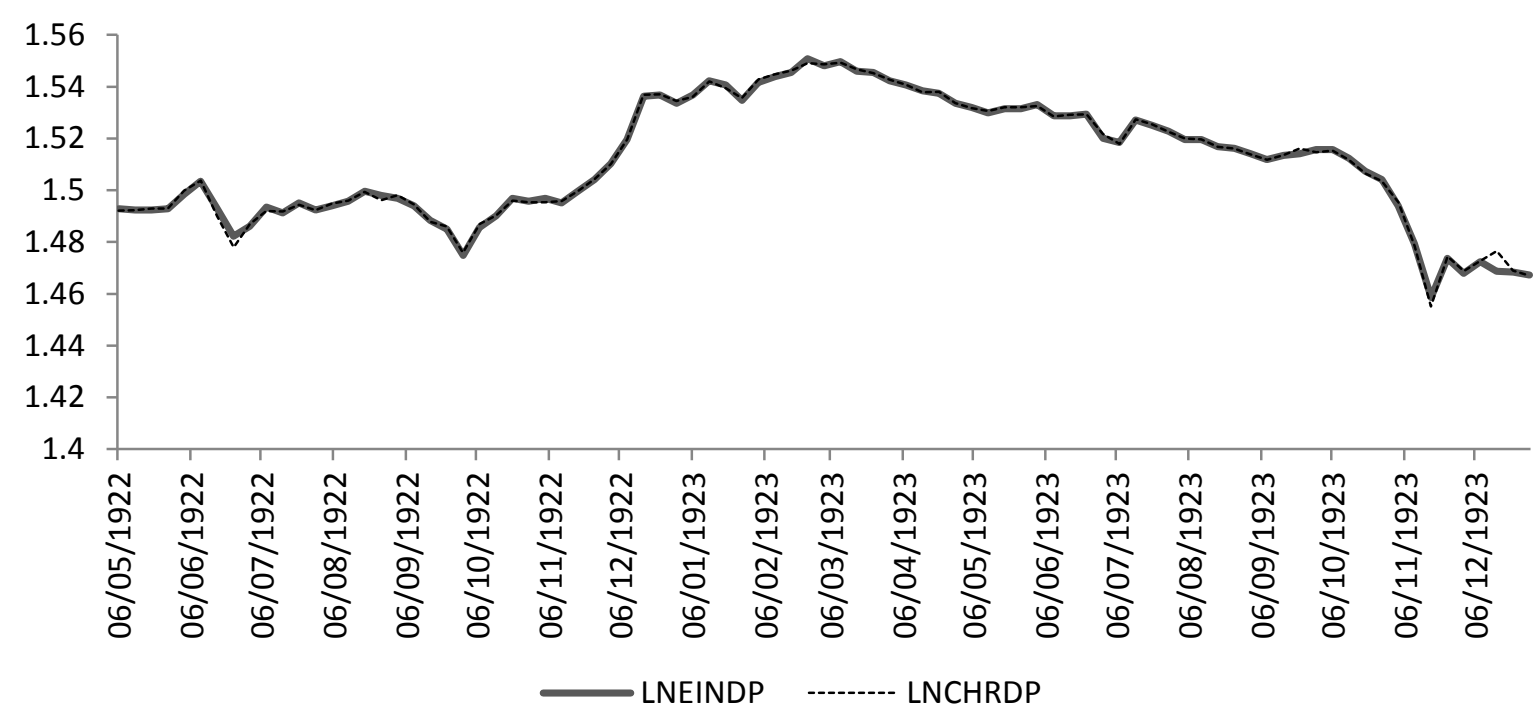

Notes: $L N E I N D P=$ US dollar/British pound Saturday quotations (in logs) from Einzig (1937)

LNCHRDP = US dollar/British pound Saturday quotations (in logs) from The Chronicle

To further illustrate the similar properties of the data, we estimate a simple regression between the logarithms of the two quotations. The results, reported below, show that The Chronicle data is an unbiased and efficient predictor of Einzig's (1937) data. The Saturday quotes for the US Dollar/British pound from the two sources usually only differ in the third decimal point.

$$
\begin{gathered}
\text { LNEINDP }=0.003+0.998 \text { LNCHRDP } \\
(0.009) \quad(0.006) \\
\bar{R}^{2}=0.997 \\
\text { DW }=1.87
\end{gathered}
$$

Standard errors are in ( ). 


\section{Appendix B}

\section{Other European Interwar Hyperinflations: Austria, Hungary and Poland}

This section focuses on three other episodes of post-World War I hyperinflation, namely those witnessed by Austria, Hungary and Poland. These had been covered in the pioneering study of Cagan (1956). Fischer et al. (2002) date these hyperinflations as follows: Austria: October 1921- August 1922, Hungary: March 1923 - February 1924 and Poland: January 1923-January 1924.

\section{Austria}

Figure A2.1 below illustrates the daily changes in the US dollar/Austrian krone exchange rate during the hyperinflation episode October 1921- August $1922^{17}$. These are complemented by a set of descriptive statistics provided in Table A2.The movements in the Austrian crone's exchange rate against the US Dollar have not been as erratic as those recorded by the German reichsmark. Out of the 277 observations considered here, 157 correspond to a depreciation of the Austrian krone, whilst 120 record an appreciation on a daily basis. October 1921 has been a month of extreme volatility, with sequences of appreciations and depreciations: for instance, October 18 - October 19, when the crone appreciated by $17 \%$ during one day. Substantive depreciations of the crone occurred on 3 November 1921, 13 June 1922 (22.31\%), 1 August 1922 (24.11\%) and 2 August 1922 (25.78\%). Major appreciations occurred on 1 December 1921 (21.11\%) and 12 December 1921 (18\%).

\footnotetext{
${ }^{17}$ The available data starts at the end of May 1921, but here we chose to focus on the hyperinflation period (October 1921August 1922), which amounts to 277 daily observations.
} 
FIGURE A2.1

DAILY RATES OF CHANGE IN THE US DOLLAR/AUSTRIAN KRONE EXCHANGE RATE OVER THE HYPERINFLATION PERIOD OCTOBER 1921 - AUGUST 1922

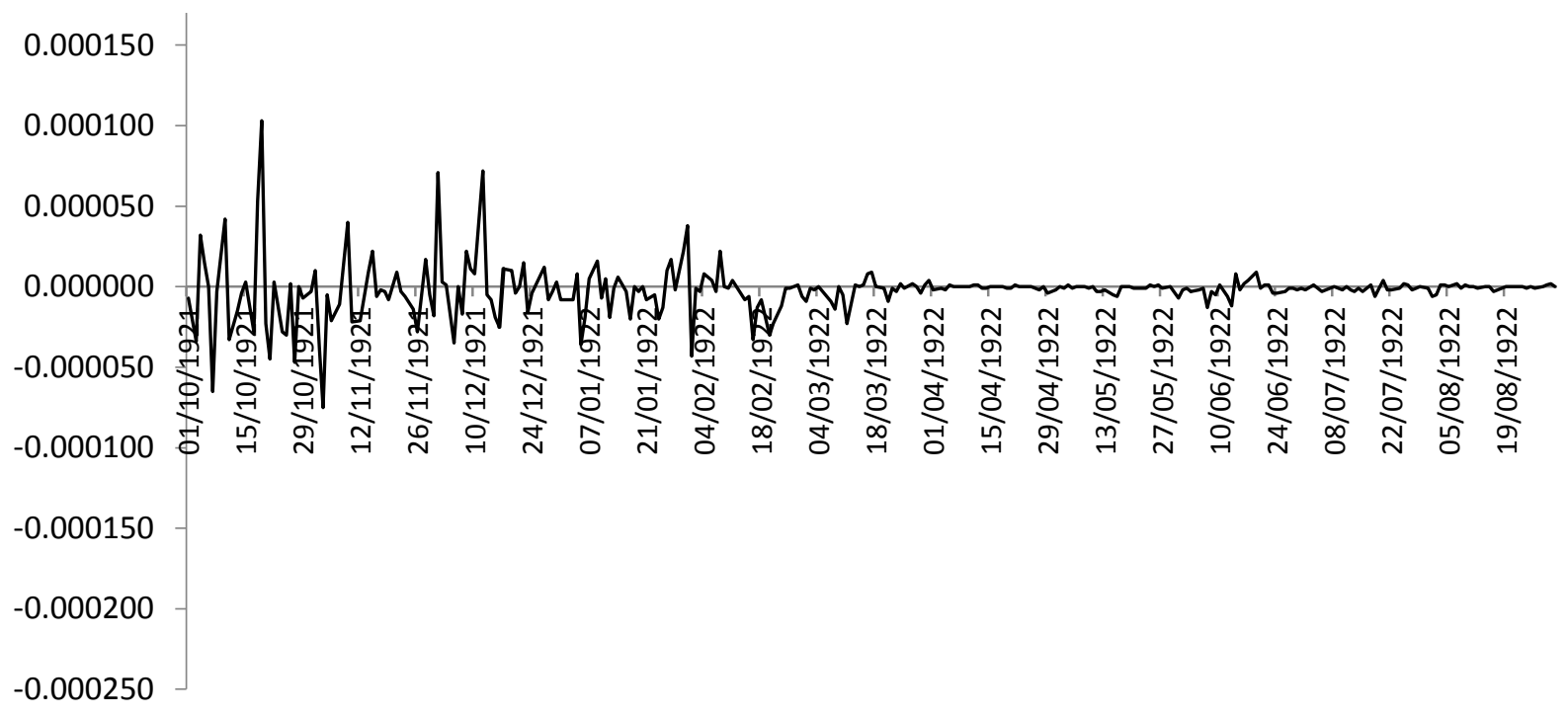

TABLE A2

DESCRIPTIVE STATISTICS FOR THE DAILY RATE OF CHANGE OF THE US DOLLAR/AUSTRIAN KRONE (DAUST), THE US DOLLAR/HUNGARIAN KRONE (DHUNG), THE US DOLLAR/ POLISH MARK (DPOL) EXCHANGE RATES OVER THEIR RESPECTIVE HYPERINFLATION PERIODS

Descriptive

DAUST

DHUNG

DPOL

Statistics October 1921-August March 1923 - February January 1923-January 1922 1924

1924

\begin{tabular}{lccc}
\hline Mean & -0.0133 & -0.0081 & -0.0191 \\
Median & -0.0075 & 0.0000 & 0.0000 \\
Maximum & 0.2111 & 0.2429 & 0.1541 \\
Minimum & -0.2578 & -0.6678 & -0.3198 \\
Std Deviation & 0.0575 & 0.0551 & 0.0693 \\
Skewness & -0.2642 & -5.6618 & -0.9644 \\
Kurtosis & 7.0573 & 73.4909 & 5.6794 \\
\hline
\end{tabular}




\section{Hungary}

The biggest daily depreciation was recorded on 26 July 1923 (66.78\%). Out of 296 daily changes observed during the hyperinflation episode considered here, 105 correspond to depreciations, with the remaining 191 witnessing either no changes in the value of the Hungarian crone or occasional appreciations.

FIGURE A2.2

DAILY RATES OF CHANGE IN THE LOG US DOLLAR/HUNGARIAN KRONE EXCHANGE RATE OVER THE HYPERINFLATION PERIOD MARCH 1923 - FEBRUARY 1924

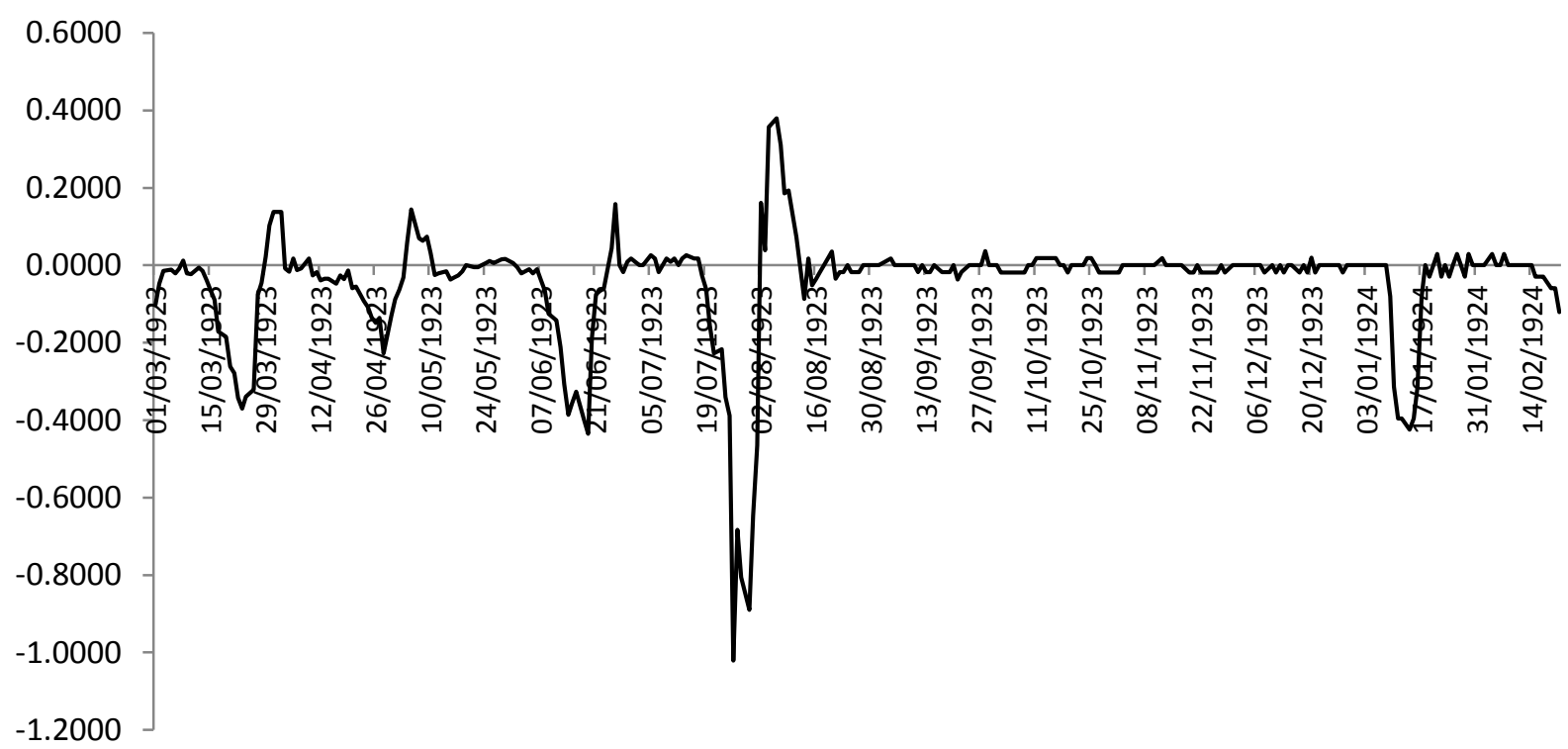

Poland

Over the 1-year period that Sahay et al (2002) highlight as the Polish hyperinflation episode (January 1923-January 1924), the value of the Polish mark against the US dollar depreciated by $99.8 \%$. Out of 327 daily changes recorded over the period under scrutiny here, 141 correspond to depreciations, with the largest daily depreciation having been recorded on 27 October 1923 (31.98\%). The biggest daily appreciation (15.41\%) took place on the 27 July 1923. 
FIGURE A2.3

DAILY RATES OF CHANGE IN THE LOG US DOLLAR/POLISH MARK EXCHANGE RATES OVER THE HYPERINFLATION PERIOD JANUARY 1923 - JANUARY 1924

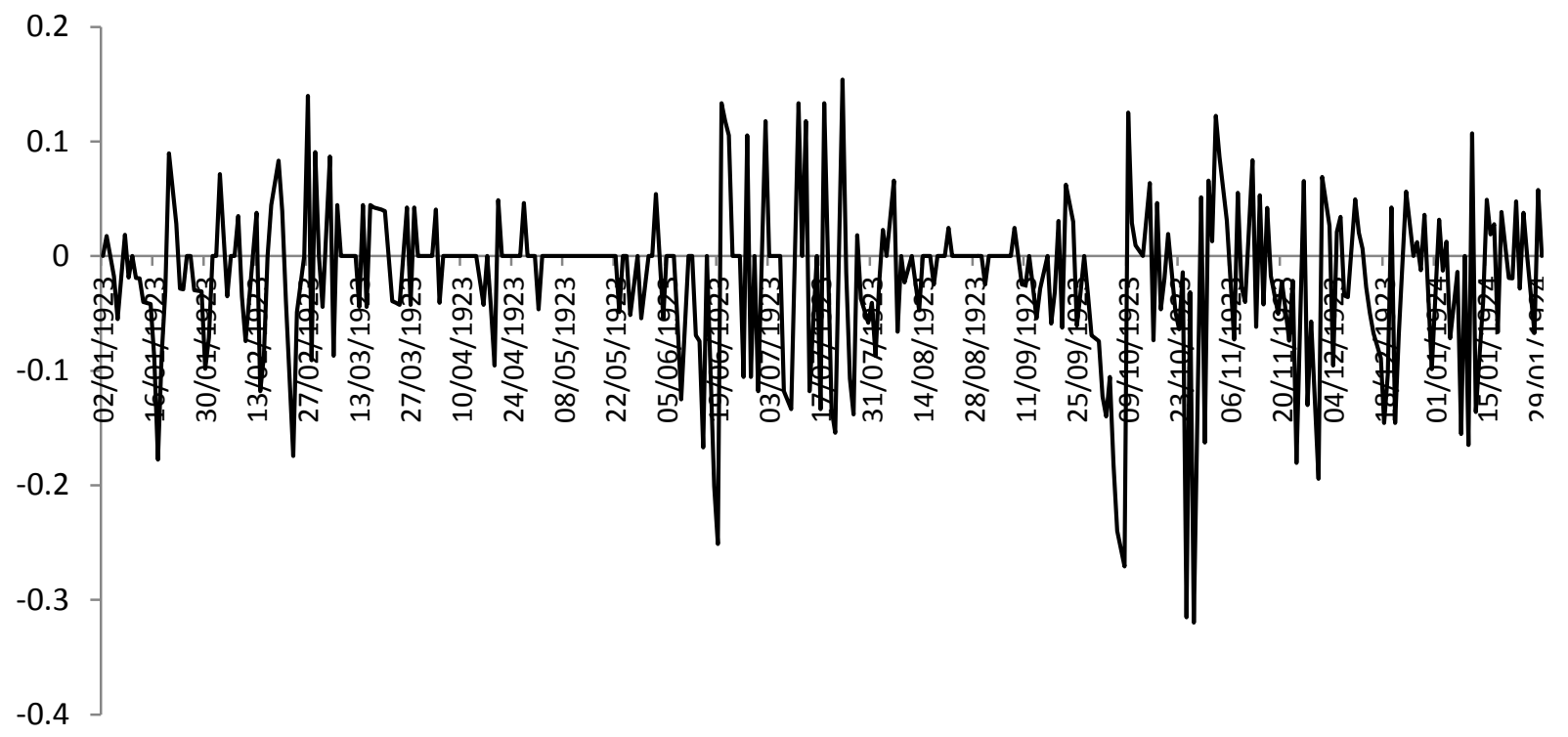




\section{References}

Abel, Andrew, Dornbusch, Rudiger, Huizinga, John, and Marcus, Alan 1979. "Money Demand During Hyperinflation.” Journal of Monetary Economics 5 (January 1979): 97-104.

Bernanke, Ben S. "The Economics of the Great Depression: An Interview with Ben Bernanke.”, 2005, available at: http://www.ecu.edu/cs-educ/econ/upload/Ben Bernanke.pdf [Accessed February 2012].

Bresciani-Turroni, Constantino. The Economics of Inflation: A Study of Currency Depreciation in Post-war Germany, G. Allen \& Unwin: London, 1937.

Cagan, Phillip D. "The Monetary Dynamics of Hyperinflation.” In Studies in the Quantity Theory of Money, edited by Milton Friedman, University of Chicago Press: Chicago, 1956.

Casella, Alessandra. "Testing for Rational Bubbles with Exogenous or Endogenous Fundamentals. The German Hyperinflation Once More.” Journal of Monetary Economics 24 (July 1989): 109-22.

Einzig, Paul. The Theory of Forward Exchange, Macmillan: London, 1937.

Engle, Robert F., and Granger, Clive W. J. "Cointegration and Error-Correction: Representation, Estimation, and Testing." Econometrica 55 (March 1987): 251-276.

Evans, George.W., Honkapohja, Seppo, and Marimon, Ramon. "Convergence in Monetary Inflation Models with Heterogeneous Learning Rules.” Macroeconomic Dynamics 5 (February 2001): 1-31.

Flood, Robert P., and Garber, Peter M. "An Economic Theory of Monetary Reform." Journal of Political Economy 88 (February 1980): 24-58.

Flood, Robert P., and Garber, Peter M. "Process Consistency and Monetary Reform: Some Further Evidence.” Journal of Monetary Economics 12 (August 1983): 279 -95.

Frenkel, Jacob. A. "The Forward Exchange Rate, Expectations, and the Demand for Money: The German hyperinflation.” American Economic Review 67 (September 1977): 653-70.

Frenkel, Jacob A. "Purchasing Power Parity: Doctrinal Perspective and Evidence from the 1920s.” Journal of International Economics 8 (May 1978): 169-91. 
Frenkel, Jacob A. "Further Evidence on Expectations, and the Demand for Money During the German Hyperinflation.” Journal of Monetary Economics 5 (January 1979): 81 - 96.

Frenkel, Jacob A. "Exchange Rates, Prices, and Money: Lessons from the 1920's." American Economic Review 70 (May 1980), 235-42.

Graham, Frank O. Exchange, Prices and Production in Hyperinflation Germany, Princeton University Press: Princeton, 1930.

Hansen, Lars. P., and Hodrick, Robert, J. "Forward Exchange Rates as Optimal Predictors of Future Spot Rates: An Econometric Analysis." Journal of Political Economy 88 (October 1980): 829-53.

Hsieh, Cheung-Tai, and Romer, Christina D. "Was the Federal Reserve Constrained by the Gold Standard During the Great Depression? Evidence from the 1932 Open Market Purchase Program.” Journal of Economic History 66 (March 2006): 140 - 76.

Krugman, Paul R. "Essays on flexible exchange rates." Ph. D. dissertation, Massachusetts Institute of Technology, Dept. of Economics, 1977.

LaHaye, Laura. "Inflation and Currency Reform.” Journal of Political Economy 93 (June 1985): 537 60.

Michael, Panos, Nobay, Robert. A., and Peel, David A. "The German Hyperinflation and the Demand for Money Revisited.” International Economic Review 35, (February 1994): 1-22.

Michael, Panos, Nobay, Robert A., and Peel, David A. "Transactions Costs and Nonlinear Adjustment in Real Exchange Rates: An Empirical Investigation." Journal of Political Economy 105 (August 1997): 862-79.

Peel, David. A., and Taylor, Mark P. "Covered Interest Rate Arbitrage in the Interwar Period and the Keynes-Einzig Conjecture.”, Journal of Money, Credit and Banking 34 (February 2002): 51-75.

Sargent, Thomas J. "The Ends of Four Big Inflations." In Inflation: Causes and Effects, edited by Robert E. Hall, University of Chicago Press: Chicago, 1982.

Sargent, Thomas J., and Wallace, Neil. "Rational Expectations and the Dynamics of Hyperinflation." International Economic Review 14 (June 1973), 1043-48. 
Smith, G. W. and Spencer, M. G. "Estimation and Testing in Models of Exchange-Rate Target Zones and Process Switching." In Exchange Rate Targets and Currency Bands, edited by Paul Krugman and Marcus Miller, Cambridge University Press: Cambridge, 1991.

Taylor, Mark P., and McMahon, Patrick C. "Long-run Purchasing Power Parity in the 1920s.", European Economic Review 32 (November 1988): 179 -97.

The Commercial and Financial Chronicle, Vols 112-116 (1921-1923), William B Dana Company.

Webb, Steven B. "Fiscal News and Inflationary Expectations in Germany After World War I.", The Journal of Economic History 46 (September 1986): 769-94. 